\title{
Finansal Sistemin Karaparanın Aklanması Ve Terörizmin Finansmanı Girişimleri İle İlgili Karşılaştığı Riskler Ve Türkiye’nin Bu Alandaki Uluslararası Uyumunun Analizi
}

İlhan ŞAHİ**

\section{$\ddot{O Z Z T T}$}

Finansal sistem ve özünde finansal kuruluşlar hem yurt içi hem de yurt dişından karaparanın aklanması ve terörizmin finansmanı amacını taşıyan çeşitli girişimlere maruz kalabilmektedir. Bu durum çeşitli riskleri beraberinde getirmektedir. Söz konusu girişimlere karşı yeterli tedbirlerin alınmaması veya finansal kuruluşların bu türden faaliyetlerle iliş̧kilerinin olması gerek finansal kuruluşun ve sektörün, gerekse ülkenin uluslararası itibarına zarar vermektedir. FATF adlı kuruluş, ülkelerin söz konusu alandaki uyumunu izleyen ve değerlendiren en etkin uluslararası kuruluştur. Bu çalışmanın amacı, FATF tarafindan yakın dönemde yayınlanan dökümanlar baz alınarak Türkiye'nin söz konusu alandaki uluslararası иyumunu analiz etmektir. Bu çerçevede, FATF'ın Türkiye hakkında hazırladı̆̆ yakın dönemdeki raporlar ve kamuoyu açıklamaları Türkiye'nin uluslararası alanda önemli ölçüde itibar sorunu yaşadı̆̆ı izlenimi vermektedir. Yapılan analiz sonucunda, Türkiye'nin çoğu az gelişmiş veya gelişmekte olan ülke ile aynı kategoride yer aldiğı tespit edilmiştir. Türkiye'nin bir yandan FATF üyesi olup diğer yandan FATF tarafindan belirlenen riskli ülkeler kategorisinde yer almast sadece Türkiye'nin değil, aynı zamanda FATF'ın da uluslararası itibarın zedelemektedir. Dolayısıla, Türkiye FATF tarafından yayınlanan dökümanlarda belirtilen eksiklikleri dikkate alarak uluslararası uyumu sağlayacak yönde politikalar uygulamalıdır.

Anahtar Kelimeler: Karapara Aklama, FATF Raporları, Terörizmin Finansmanı, Yüksek Riskli ve İşbirliği Yapmayan Ülkeler, Uluslararası Uyum.

JEL Sinıflandırmasi: G18, G20, F51, F55.

The Risks Encountered By Financial System Related To The Attempts Of Money Laundering And Financing Terrorism And Analysis Of International Complance Of Turkey In This Area

\section{ABSTRACT}

Financial system and financial institutions may be exposed to various attempts with the aim of money laundering and financing terrorism from both domestic and abroad. This situation poses several risks. Not taking adequate measures against these attempts or being associated financial institutions with these kind of activities impair international reputation of both financial institution and sector and also country. The institution named FATF is the most effective international institution which monitors and evaluates compliance of countries in this area. The purpose of this study is to analyze international compliance of Turkey in the area in question on the basis of documents published by FATF. In this context, in the last period of the reports and public statements prepared by FATF about Turkey give an impression that Turkey lives considerable international reputation problem in the international arena. As a result of the analysis, it is determined that Turkey takes place on the same category with the most of underdeveloped and developing countries. On the one hand, Turkey's being a member of FATF, on the other hand, taking place on the category of risky countries determined by FATF damages international reputation not only Turkey but also FATF as well. Consequently, Turkey should implement policies in the direction of ensuring international compliance by taking into account deficiencies mentioned in the documents issued by FATF

Keywords: Money Laundering, FATF Reports, Financing Terrorism, Non-Cooperative Countries or Territories, International Compliance.

Jel Classification: G18, G20, F51, F55.

* Dr. İlhan Şahin, T. Vakıflar Bankası T.A.O, Müdür Yardımcısı, e.mail: ilhan.sahin@ vakifbank.com.tr 


\section{GíRiş}

Karaparanın aklanması ve terörizmin finansmanının önlenmesine ilişkin uluslararası düzenlemelere uyumun sağlanması küresel finansal sisteme entegrasyon için bir zorunluluk haline gelmiş̧ir. Karaparanın aklanması ve terörizmin finansmanının önlenmesi girişimlerine karş1 son yıllarda giderek güçlenen eğilimlerin sonucu ülkeleri etkin bir şekilde izleyen, denetleyen ve söz konusu faaliyetler ile ilgili olarak ülkeler hakkında raporlar hazırlayan kuruluşlar teşkil edilmiştir. Bu kuruluşlardan en önemlisi OECD nezdinde teşkil edilen FATF (Financial Action Task Force-Uluslararası Mali Eylem Görev Gücü) adlı kuruluştur.

Ülkeler ve bankalar gibi çeşitli finansal kuruluşların bu alanda faaliyet gösteren FATF gibi bazı uluslararası kuruluşlar tarafından belirlenen düzenlemelere uyum sağlayıp bunları uygulamaları, uluslararası alanda faaliyet göstermeleri açısından önem arz etmektedir. Zira, uluslararası kuruluşların ülkeler ve finansal kuruluşlar hakkında yaptıkları izleme faaliyetleri sonucunda haklarında hazırladıkları raporlarda belirttikleri uyumsuzluk ve aksaklıklar, küresel piyasalarda dikkate alınmakta ve söz konusu uyumsuzluklar diğer ülkelerin, bu ülkeler ve buralarda bulunan finansal kuruluşlar ile iş ilişkisine girmekten kaçınmalarına neden olmaktadır. FATF adlı kuruluşun yaptı̆̆ çalışmalar ve bu çerçevede hazırladığı raporlar incelendiğinde, küresel arenada bazı ülkeler ve bu alanda yükümlülük atfedilen finansal kuruluşların, uluslararası mevzuata sağladıkları uyum ve uygulamalarının etkinliğinin yeterli seviyede olmadığı ortaya çıkmaktadır.

$\mathrm{Bu}$ kapsamda, çalışmamızda öncelikle karaparanın aklanması ve terörizmin finansmanının önlenmesine ilişkin uluslararası düzenlemelere uyum yetersizliğinin finansal kurumlar ve ülke açısından yarattığı risklere ve söz konusu risklerin etkilerinin değerlendirmesine yer verilmiştir. Ayrıca, FATF tarafından yüksek riskli ve işbirliği yapmayan ülkeler hakkında 2010 yılından günümüze kadarki yakın dönemde yayınlanan raporlar ve kamuoyu açıklamaları incelenerek Türkiye'nin bu alanda yaşadığı uyum yetersizliğinin gerek Türkiye ekonomisi gerekse Türk finans sektörünün uluslararası ölçekte gösterdiği faaliyetlerde yaratabileceği risklerin değerlendirmesi ve analizi yapılmıştır.

\section{KARAPARANIN AKLANMASI VE TERÖRIZMIN FINANSMANININ ÖNLENMESINE İLISŞKİN ULUSLARARASI DÜZENLEMELERE UYUM YETERSIZLIIĞININ FINANSAL KURUMLAR AÇISINDAN YARATTIĞI RISSKLER}

Ülkelerin uluslararası arenada sahip olduğu itibar gibi, bankacılık sektörünün de temeli güven ve itibardır. Toplumda fon arz eden ve fon talep eden taraflar arasinda aracılık işlevini yerine getirerek ülke ekonomisinde önemli bir rol oynayan bankaların aynı zamanda, kârlılık ve verimlilik ilkelerini amaç edinmiş olmaları, mesleki ve örgütsel alanda kamu otoritelerinin koyduğu yasa, yönetmelik ve etik ilkelere bağlı olarak çalışmaları zorunluluğunu getirmektedir (Çakır, 2006:42). 
Karaparanın aklanması ile ilgili faaliyetler genellikle gelişmemiş ve gelişmekte olan ülkeler ile küçük ülkelerde yoğunlaşmaktadır. Özellikle küçük veya ekonomik olarak alt gelir grubunda yer alan ülkeler karaparanın aklanmasına daha fazla açık ve duyarlıdır. Yasadışı faaliyetlerden elde edilen kazançlar söz konusu ülkelerin ekonomilerinde yarattığı kaldıraç etkisi ile organize suç örgütlerine potansiyel olarak büyük bir ekonomik güç sağlamaktadır (UNODC, 2005:1).

Bir ülkede karaparanın aklanmasının önlenmesi ile ilgili yeterli kontrol sistemlerinin olmaması ya da bunların uygulanamaması suçlulara yasadışı faaliyetleri sürdürme imkanı sağlar. Yasadışı faaliyetlerden elde edilen gelirlerin aklanması ile ilgili yeterli önlemlerin alınmadığı ülkelerde suçlular için sadece bir amacın söz konusu olduğundan bahsedilebilir. $\mathrm{Bu}$ da suç gelirlerinden cezasız bir şekilde faydalanmak için ülkenin yapısal zayıflıklarını ya da kurumsal ve yasal mevzuat araçlarındaki açı̆̆ı istismar etmektir. Karapara aklama kâr doğuran herhangi bir suçun, önemli bir yönü ve organize suçun kaçınılmaz doğal bir sonucudur. Yasadışı kazançların birikimine yönelik olarak yönetilen organize suç örgütlerinin faaliyetleri, küçük grupların elinde gelişmiş ve yoğunlaşmış ölçüde söz konusu faaliyetlerle doğru orantılı olarak para aklama için ihtiyaç yaratır. Uyuşturucu kaçakçılığı gibi bazı suçlardan elde edilen devasa miktarda nakit paranın aklanması suçun işlenmesi esnasında bırakılan izlerden daha fazla iz yaratır ve bunları gizlemek daha zordur (UNODC, 2005:1-2).

Beekarry (2011:138-139) karaparanın aklanması ile ilgili risklere ilişkin endişeler ve küresel finansal istikrar için oluşturduğu tehditlerin, finansal kuruluşların likidite sorunları yaşadığı son küresel finans krizinde daha belirgin bir biçimde yeniden ortaya çıktığını vurgulamaktadır. Zira, Beekarry krizde likidite ihtiyacı duyan bankaların, özellikle uyuşturucu ve yasadışı faaliyetlerden elde edilen paraların varlığına dair işaretlerin bulunduğu bankalararası piyasalardan borçlanmalar yaparak hayatta kaldıklarını ifade etmektedir. Beekarry söz konusu endişelerin, suç örgütlerinin krizde hayatta kalmaya çalışan işletmelerin kontrolünü satın alıp ele geçirmek suretiyle bu işletmelere aktardıkları fonların dünyanın farklı bölgelerinde finansal sektörlere sızmasına ilişkin faaliyetlere dayandığını belirtmektedir.

Basel Bankacılık Komitesi ve dünyanın önde gelen ulusal denetleyici ve düzenleyici kuruluşlar, karaparanın aklanması ve terörizmin finansmanının önlenmesi konusunda çeşitli risk odaklı denetim modelleri benimsemiş ve karşılaşılabilecek riskleri modeller içinde tanımlamışlardır. Ancak anılan kuruluşların modellerinde yer alan risk kategorileri arasında likidite ve faiz oranı riski gibi riskler, karapara aklama ve mali suç ile doğrudan ilgisi kurulamadığından ve minimal seviyelerde ilişki kurulabileceği düşüncesinden hareketle risk tanımlamalarına dahil edilmemişlerdir. Genellikle dört ana kategori altında incelenen riskler, operasyonel, uyum, itibar ve stratejik risk adları altında tanımlanmışlardır (IFAC, 2004:12). $\mathrm{Bu}$ kapsamda, söz konusu sınıflandırma da dikkate alınarak çalışmamızda, karaparanın aklanması ve terörizmin finansmanının önlenmesine ilişkin uluslararası düzenlemelere uyum yetersizliğinin finansal kurumlar açısından yarattığı riskler ülke, operasyonel, yasal, faaliyet, 
itibar ve yoğunlaşma riskleri olmak üzere 6 ana başlığa ayrılmış, bahsi geçen risk sınıflandırmasında yer alan uyum riski, yasal risk; stratejik risk ise faaliyet riski kapsamında incelenmiştir.

\section{1. Ülke Riski}

Ekonomik bir kavram olan suç gelirlerinin aklanmasının engellenmesi, uyuşturucu ticareti ve diğer organize suçlara karşı en etkili silah olarak görülmeye başlanmasıyla birlikte hukukun ilgi alanına girmiştir. 20. yüzyılın son çeyreğinde suç örgütlerinin fiillerinden doğan kazançların yasal ekonomi içine dahil edilerek aklanmasının engellenmesi, öncül suçlarla bağlantısının tespit edilerek el konulması için kimi ülkeler ayrı bir yasa ile kimi ülkeler de mevcut yasalarında değişikliklere giderek para aklanmasını ciddi ve müstakil bir suç olarak tanımlamaya başlamışlardır (Çakır, 2010:69-70).

Ancak, suç gelirleriyle mücadelenin yerel ölçekte yeterli olmaması ve zaman içinde suç ve suça ilişkin gelirin sınır aşan niteliğe kavuşması, mücadelenin uluslararası boyut kazanmasına neden olmuştur. Bu kapsamda suç gelirleriyle mücadele için hem uluslararası örgütler nezdinde hem de bazı ülkelerin katılımıyla kendi başına faaliyet gösteren uluslararası kuruluşlar teşkil edilmiş ve küresel ölçekte uyulması gereken kurallar bütünü oluşturulmuştur. Söz konusu kuruluşlar arasında, dünya ölçeğinde yer alan tüm ülkeler hakkında izleme yapan ve raporlar hazırlayan FATF adlı kuruluş, bu alanda ülkelerin karnesini belirler bir rol üstlenmiştir. Başta uluslararası ölçekte faaliyet gösteren ülkeler olmak üzere diğer ülkeler de, herhangi bir ülke ile ekonomik ve mali ilişkisinin seviyesini belirlerken ekonomik ve mali faktörlerin yanında FATF'ın hazırladığı raporları da dikkate almak durumunda kalmışlardır.

$\mathrm{Bu}$ itibarla, karaparanın aklanmasının önlenmesi konusu kapsamında ülke riskinin, ülkenin hem kendi mevzuat ve uygulamalarının uluslararası uyumundan kaynaklanabilecek eksiklik veya yetersizliklerden, hem de diğer ülkeler ile kurduğu mali ve ekonomik ilişkilerinden kaynaklanabilecek sorunlardan doğabilecek risklere karşıllk geldiği söylenebilir. Bunun yanında finansal kuruluşların suç gelirleri ile mücadelede uluslararası mevzuat, kural ve kaideleri yerine getirmemesi ya da suç gelirleri ile ilişkilendirilmesi finansal kuruluşun bulunduğu ev sahibi ülke için risk yaratır. $\mathrm{Bu}$ anlamda ülke riskinin, suç gelirleri ile mücadelede bizzat ülkenin fiili devlet ve kurumları tarafından yerine getirilmeyen mevzuat yetersizlikleri, ihlalleri ya da suç gelirleri ile ilişkilendirilmesinden kaynaklanan riskler veya finansal sistemin suç gelirlerinden dolayı ülke için yarattığı riskler olduğundan bahsedilebilir.

Bu durumu Kutubi (2011:37), bir finansal kuruluşun karaparanın aklanması ya da terörizmin finansmanı fiillerine farkında olmadan bulaşmasının sadece kendi itibarına değil, aynı zamanda ülke itibarına da zarar vereceğine dikkat çekerek açıklamaktadır. Ayrıca, Yetim (2000:324), karapara aklama faaliyetlerini kolaylaştıran ülkelerin ülke riski artacağından ve kredi değerlilikleri de buna paralel azalacağından bu ülkelere yapılabilecek dış kaynaklı bağış, yardım ve kredilerin de azalabileceğini vurgulamaktadır. Bu kapsamda, ülkeler ve finansal sistemleri için önemli bir tehdit unsuru olan suç gelirlerinin ülke ve finansal sistem açısından yarattığı olumsuz etkiler aşağıdaki gibi sayılabilir (Çakır, 2010:70): 
- Devlet, kurum ve kişilere prestij kaybettirir, ülkenin uluslararası ölçekte itibarını zedeler,

- Yasa dişıdır, ülkenin uluslararası alanda yaptırımlara maruz kalmasına neden olabilir,

- Finansal kuruluşların uluslararası işlem yeteneğinin sonlanmasına ve para cezaları ile muhatap olmasina neden olabilir,

- Uluslararası arenada ülkeye karşı güvensizlik yaratır. Ülkenin gerek ekonomik gerek finansal, gerekse diplomatik ilişkilerinin istikrarsızlaşmasına neden olur,

- Siyasal, adli, finansal ve sosyal kurumlara verilen önemi ve güveni azaltır,

- Sahteciliği, rüşveti ve ahlaksızlı̆̆ı besler,

- Birey ve toplumların sağlıklı yapısını tehdit eder.

\subsection{Operasyonel Risk}

Operasyonel veya işlem riski geleneksel olarak hizmet veya ürün sunum süreçlerinde karşılaşılan riskler olarak tanımlanır. Bu risk, dahili kontrol süreçleri, bilgi işlem sistemleri, çalışanların faaliyetleri ile birçok işletim sisteminin bir fonksiyonudur (IFAC, 2004:12). Karapara aklama ve terörizmin finansmanı ile ilgili operasyonel risklerin birçoğu, finansal kuruluşun bu kapsamdaki yükümlülükleri ve uygulamadaki zayıflıkları ile ilgilidir. Özellikle kuruluş içi kontrollerdeki aksamalar ve kuruluş yönetimindeki hatalardan kaynaklanır (Alp, 2005:79). Karapara aklama faaliyeti birçok sektörde gerçekleştirilebilirken, bankacılık sektörünün ekonominin fon akış döngüsü içinde odak noktada yer alması ve reel sektörde faaliyet gösteren şirket ve kurumların gerek finansal kaynak gerekse operasyonel bankacılık işlemlerine ilişkin ihtiyaçlarını çoğunlukla bu sektörden karşılamak zorunda olmaları nedeniyle, aklama girişimlerine karşı diğer sektörlere nazaran daha fazla risk sahibidir.

Bu nedenle, dünyada ve ülkeler bazında bankacılık uygulamalarını doğrudan etkileyen FATF tavsiyeleri ve Basel Bankacılık Denetim Komitesi bildirilerine göre; bankaların karapara aklama girişimlerine karşı müşteri kaynaklı operasyonel risklerini indirgeyecek esasları içeren "Müşterini Tanı İlkesi” büyük önem kazanmaktadır. Söz konusu ilke, basit kimlik tespiti ile hesap açma ve kayıt tutmanın ötesinde, bankaların risk bazlı bir biçimde müşterini tanı uygulamalarının geliştirilmesini gerektirmekte, aynı zamanda yüksek risk içeren sektör, kişi ve kurumlar için üst düzey yönetici onayı dahil müşterinin tanınması ve kabulüne ilişkin detaylı yazılı politika ve kuralların oluşturulmasını içermektedir. Ayrıca bahsedilen ilke gereği, müşteri ve hesap türünden beklenen normal işlemler dışındaki şüpheli faaliyetlerin izlenmesi ve raporlanması zorunlu olmaktadır (Çakır, 2010:72). Karaparanın aklanması ve terörizmin finansmanına ilişsin girişimler, teknolojinin geldiği seviye dikkate alınarak bu alandaki gelişmelere göre gerek finansal kuruluş gerekse finansal kuruluşları denetleyen kurumlarca güncellenebilen risk odaklı sistemlerin kurulumu ile kontrol altına alınabilmektedir. 


\subsection{Yasal Risk}

Yasal risk, finansal kuruluş aleyhinde dava açılması, yargılama yapılması veya sözleşmeler nedeniyle bankanın durumunun veya operasyonlarının ters yönde etkilenme ihtimalini ifade eder. Dünyada bankalar, karapara aklamayla mücadele çerçevesinde kendilerine getirilen yükümlülüklerini yerine getirmemeleri nedeniyle ciddi yasal risklerle karşı karşıya kalmaktadır. Örneğin ABD'de uluslararası nitelikte bir banka, sadece iki çalışanının karapara aklama suçundan dolayı mahkum olması sonucu, 50 milyon dolar para cezasına çarptırılmıştır. Bazı ülkelerde, bankanın yükümlülük ihlallerinin süreklilik arz etmesi durumunda, bankacılık lisanslarının iptali yoluna dahi gidilebilmektedir (Alp, 2005:77). Dolayısıyla karapara aklama veya terörizmin finansmanı ile mücadelede mevzuat, yükümlülük ve uygulamaya yönelik ihlaller, bir süre sonra bankaların faaliyetlerinin tamamen durdurulmasına varan cezai kararların alınıp uygulanmasına neden olabilmektedir.

Bankalar ve çoğu banka dişı finansal kuruluş risk odaklı denetime tabi olup, denetimler sonunda gerekli uyumu sağlamakla yükümlüdürler. Buna göre yasal risk çatısı altında daha spesifik olarak değerlendirilebilecek uyum riski ise finansal kuruluşun karaparanın aklanmasının önlenmesi ile ilgili uyum programı geliştirme, müşterini tanı politikaları oluşturma, kayıtların tutulması, karapara aklama ile ilgili risk içeren işlemlerin izlenmesi ve raporlamaların yapılmasına ilişkin fonksiyonlara uyumun bütününü teşkil eder. Müşterini tanı politikalarının oluşturulması, yükümlü kuruluşların şüpheli işlem bildirimlerini yapabilmeleri açısından özellikle önemlidir (IFAC, 2004).

Yasal risk, öncelikle uluslararası mevzuat ve düzenlemelere karşı ülkenin uyumunu, sonrasında ise bankacılık gibi alt sektör veya kurumların bütününün uyumunu kapsar. Karaparanın aklanması ve terörizmin finansmanının önlenmesi girişimlerinin engellenmesi ve bu alandaki risklerin azaltılması için ülke mevzuatının yeterli seviyede olması, finansal kuruluşların elini güçlendirir ve faaliyetlerini daha güven dolu bir ekonomik ortamda yürütmeleri imkanını yaratır. Yasal mevzuat altyapısı güçlü bir ülkede faaliyet gösteren finansal kuruluş aynı zamanda gerçekleștirdiği sağlıklı faaliyetleriyle, uluslararası finansal sistem içinde itibar kazanır.

\subsection{Faaliyet Riski}

Bir banka ve hatta evsahibi ülke hakkındaki karapara aklama iddiası o banka ile ülkenin ulusal ve uluslararası düzenleyici ve denetleyici bankacılık otoriteleri, müşterileri, ortakları, yurt dışı muhabirleri ve kamuoyunda güvenilirliğine, saygınlığına, ulusal ve uluslararası itibarına büyük bir darbe olmaktadır. Karapara aklama soruşturma ve davaları olayın uluslararası boyutu nedeniyle uzun yıllar almaktadır. Bu ise, iddiaya muhatap bankaları yıpratmakta, bazen Batı'da örnekleri görüldüğü üzere iflasa kadar varan sonuçlara yol açmaktadır (Çakır, 2006:42).

Faaliyet riski kapsamında incelenebilecek olan stratejik risk ise, bir işin, ürünün veya faaliyetin etkin bir şekilde planlanması ve uygulanması esnasında ve bulunduğu sektör içindeki değişikliklere ve gelişmelere (rekabet, regülasyonlar vb.) yanıt verememesi ile ilgili 
karşılaşılan riskler olarak tanımlanabilir. Karapara aklama ile ilgili açık ve eksikliklerin bulunduğu bir pazarda işletme veya finansal kuruluşun faaliyetlerini sürdürmesi veya ürün sunumuna ilişkin riskler stratejik risk kapsamında değerlendirilir. Bunların ne derece tolere edilebileceği bu risk kapsamında analiz edilerek, finansal kuruluşun ürünü sunup sunmayacağı veya bulunduğu pazarda faaliyetine devam edip etmeyeceği kararlaştırılır (IFAC, 2004:13). Gelişmiş bir ülkede kurulu uluslararası bir bankanın türev ürünler ile ilgili faaliyetlerini az gelişmiş veya gelişmekte olan yahut FATF listelerinde yer alan ülkelerde pazarlaması, bu ürünün karapara aklamaya ilişkin taşıdığı riskin diğer finansal enstrümanlara göre daha fazla olması nedeniyle stratejik açıdan doğru olmayabilir. Bu kapsamda stratejik risk doğabilir. Aynı şekilde az gelişmiş veya gelişmekte olan ülke pazarlarına girmek ve faaliyet göstermek uluslararası alanda itibarlı bir banka için stratejik risk yaratabilir.

\section{5. İtibar Riski}

Bankalar, güven esasına dayalı olarak faaliyet gösteren mali kurumlar oldukları için, bankanın dürüstlüğü konusundaki yurt içi ve uluslararası kamuoyu görüşü, bir bankanın sahip olacağı en değerli aktiflerden biridir. Banka müşterilerinin ve piyasa katılımcılarının güveninin kazanılması ve muhafaza edilmesi bankacılık için önemli olduğundan, itibar riski bankaya önemli hasarlar verebilir. İtibar riski, kamuoyu olumsuz görüşlerinin, banka veya diğer mali kurumun faaliyet ve gelirleri üzerindeki mevcut ve olası etkilerini ifade etmektedir. $\mathrm{Bu}$ risk, bankaların yeni iş ilişkilerine girmesini engelleyebileceği gibi, mevcut iş ilişkilerinin de devamını engelleyebilecektir. İtibar riskine maruz kalan bankaların müşteri tabanının azalması ve mali bir kayıpla karşı karşıya kalmaları muhtemeldir. Özellikle karapara aklama sürecinde yer alan bankalar, itibar riski ile karşılaşırlar. Karapara aklamada kullanılan bankalar ile ilgili olarak denetim birimlerince yapılacak olası bir inceleme, bankanın kamuoyundaki itibarına önemli ölçüde zarar verir, bu da bankanın müşterileri nezdinde itibarının düşmesine ve müşteri kaybına neden olur (Alp, 2005:78).

Bankaların veya finansal kuruluşların karapara aklama faaliyetleriyle ilişkilendirilmesi ya da adlarının bu konuyla ilgili çeşitli olaylarda zikredilmesi, yatırım ve mevduat sahiplerinin bankalara olan güvenini sarsar. Azalan güven ve itibar neticesinde, gayriresmi finansal kişi ve kuruluşların faaliyetleri artabilir veya yaygınlaşabilir. Finans ya da özünde bankacılık sektörünün uluslararası alanda itibar kaybetmesi, para transfer

mekanizmalarında Hawala havale sistemleri1 gibi alternatif yolların kullanılmasına neden olabilir. $\mathrm{Bu}$ durumun elbette kirli paranın ekonomiye daha fazla bulaşmasına yol açtığı söylenebilir (Kutubi, 2011:38).

\footnotetext{
1 Hawala, fon hareketlerinin güvenli ve kolay bir biçimde gerçekleşmelerine imkan tanınması amacıyla Hindistan ve Çin'de Batı finans sistemlerinden yüzyıllar önce doğmuştur. Genellikle yasal bankacılık sistemleri dışında uluslararası değer transferlerini içerir ve güvene dayalı bir sistemdir. Ülkelerine fon göndermek isteyen tüccarlar bunları genelde bir ticaret işletmesi sahibi olan bir hawala "bankacısı" ile yatırırlardı. Küçük bir ücret karşılığında banker fonların başka bir bankerden çekilebilmesi işini düzenlerdi, bu banker de genelde başka ülkedeki bir tüccar olurdu. Günümüzde, dünyanın farklı yerlerindeki işadamlarının şirket hesaplarını üçüncü
} 
Fundanga (2003) itibar riskine karşı bankaların kolayca savunmasız bir seviyeye ulaşabileceğine dikkat çekerek suç gelirleri ile iştigal eden müşterileri tarafından illegal faaliyetlerin kurbanı ya da aracı olabileceğini belirtmektedir. Böyle bir halde bankanın adı piyasada lekelenecek ve müşteri kaybı söz konusu olacaktır. Fundanga, bu durumu Zambiya'da bir bankanın uyuşturucu gelirlerini nezdindeki hesaplarda muhafaza ettiğine dair iddialar nedeniyle kapandığına dair bir örnek ile somutlaştırmaktadır. Bankalar bu yüzden, kendilerini korumak için sürekli ve ihtiyatlı bir şekilde müşteri veri tabanlarını kontrol etmelidir. Mevduat toplama ve likiditeyi arttırma arayışı, şüpheli para kaynaklarından para kabul edilmesi konusunda baskın faktör olmamalıdır.

İtibar riski sadece ulusal sınırlar içinde geçerli değildir. Aşağıda hakkında daha detaylı bilgi verileceği üzere FATF adlı kuruluş tarafından ülkeler, karaparanın aklanması ve terörizmin finansmanının önlenmesi konularında yükümlülüklerini yerine getirip getirmedikleri ve mevzuatlarının bu alanda yeterli düzeyde olup olmadığı ile ilgili olarak düzenli olarak izlenmekte ve değerlendirmeye tabi tutulmaktadır. FATF tarafından yapılan değerlendirmelerin sonuçları uluslararası kamuoyu ile paylaşılmakta ve alınması gereken tedbirler söz konusu kuruluş tarafından yayınlanan dökümanlarda belirtilmektedir.

\subsection{Yoğunlaşma Riski}

Yoğunlaşma riski, finansal kuruluşun aktif kalemlerinin ya da özsermayesinin önemli bir kısmının aynı veya benzer bir borçlanma aracı ile fonlanmasını ve fonlamanın yapıldı ğı kişi ve gruplar arasında doğrudan ya da dolaylı ilişkinin varlığ ile oluşan riski ifade eder.

Finansal kuruluşların, borçluların tek başına ya da grup olarak olarak kullandıkları kredilerde birbirleri arasındaki ilişkilerin düzeyini ölçebilecek ve kullanım limitlerini tesis edebilecek ihtiyati tedbirleri almaları ve bunlarla ilgili bilgi-işlem sistemlerini tesis etmeleri beklenir. Yoğunlaşma riski karaparanın aklanması veya terörizmin finansmanı konusunda ise kişi, grup veya bunların birbirleri arasındaki doğrudan ya da dolaylı ilişkiler yoluyla finansal kurumun suistimal edilmesini kapsar. Finansal kuruluş bu amaçla yapılan suistimal başvuruları veya işlemlerini, cezai yaptırımlara maruz kalmamak için sürekli izleme ve tespit etme yeteneğine sahip olmalıdır (Fundanga, 2003).

taraflara uluslararası düzeyde para göndermek için kullanması ile bu süreç büyük ölçüde aynı şekilde işlemektedir. Bu şekilde, para yatırma ve çekme geleneksel finansal kuruluşlar yerine hawala bankerleri aracılığ ile yapılmaktadır. Suç gelirlerinin aklanmasının önlenmesi tedbirleri tüm dünyada hızla arttıkça, devlet denetimi dışında gerçekleştirilen hawala kullanımının suç geliri aklayanlar ve teröristler için daha da çekici hale geldiği kabul edilmektedir (Ürem, 2010). 
Şekil 1. Yoğunlaşma Riski

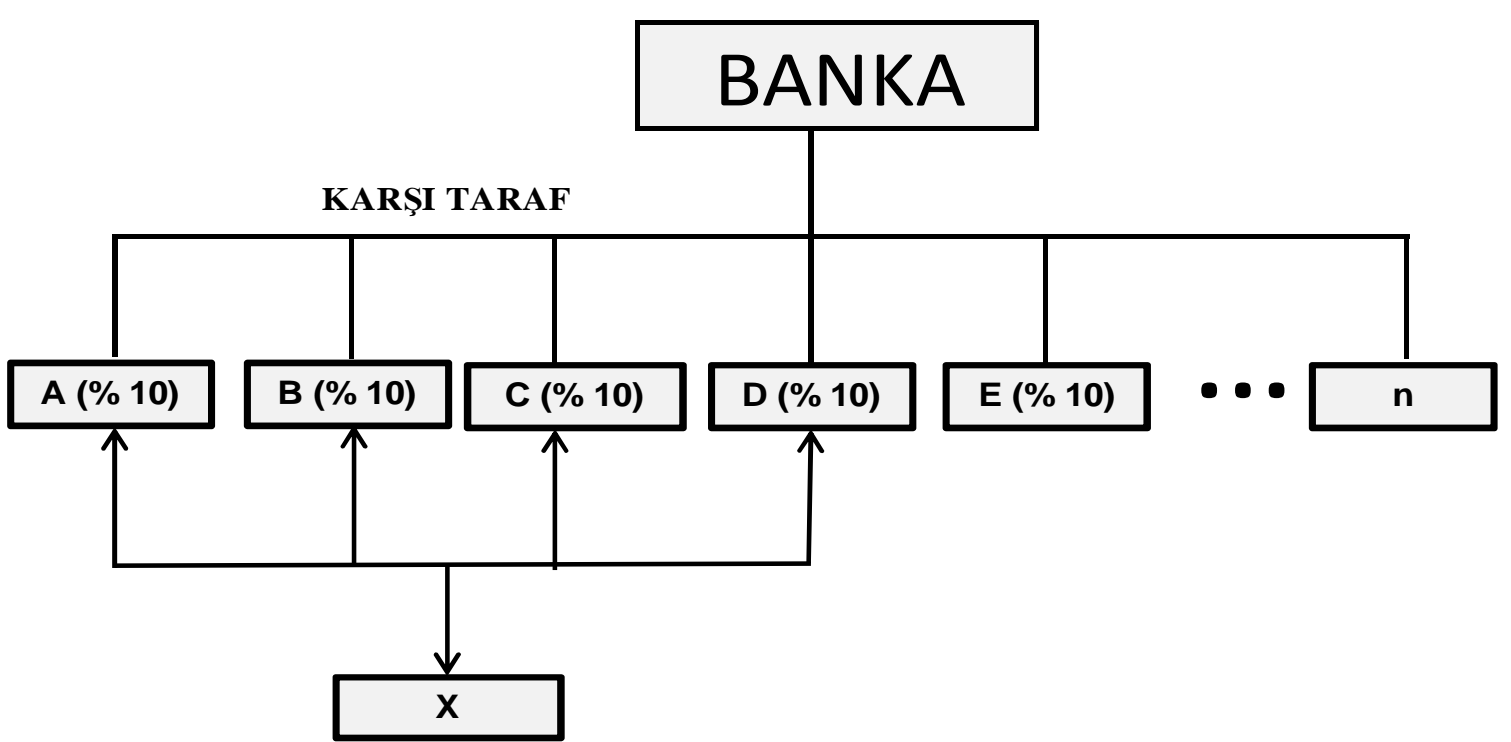

$\%$ = Banka açısından bakıldı̆̆ında bankanın iş yaptığı hiçbir karşı tarafın payı maksimum \% 10'u geçmiyor.

Kaynak: Bartlett (2002:15) ve Alp (2005)

Şekil 1'de görüldüğü üzere, karşı tarafın gerçek niteliğinin bilinmemesi durumunda finansal kuruluş ya da banka, yoğunlaşma riskinin çok düşük olduğunu tasavvur edecektir. Zira, bankanın iş yaptığı hiçbir karşı tarafın banka işlemlerindeki yüzdesi \%10'u geçmemektedir. Ancak, birbirinden tamamen bağımsız gibi görünen bu taraflar, belirli bir kişi veya grup tarafından kontrol edilebilir. Bu durumda A, B, C, D, E veya diğer kişi ve grupların yaptığı finansal işlemler yoğunluk yaratarak karaparanın aklanması konusunda finansal kuruluşun karşılaştığı yoğunlaşma riskini arttırabilir (Bartlett, 2002:15; Alp, 2005:79).

3. KARAPARANIN AKLANMASI VE TERÖRIZMIN FINANSMANININ ÖNLENMESINE ILIŞKİN FATF TARAFINDAN YAYINLANAN YÜKSEK RISKLİ VE İŞBIRLIĞİ YAPMAYAN ÜLKELER LISTESINNDE YER ALMANIN YARATTIĞI RISKLER

Karaparanın aklanması ve terörizmin finansmanının önlenmesi ile ilgili mücadelenin uluslararası alanda yaygınlaştırılması ve geliştirilmesi amacıyla OECD nezdinde teşkil edilmiş olan FATF (Financial Action Task Force-Mali Eylem Görev Gücü) adlı kuruluşun ülkeler hakkında yaptığı incelemelere ilişkin hazırladığı raporlar ve çeşitli dökümanlar, uluslarararası yatırım ve finans çevrelerince dikkate alınmakta ve ilgili ülke ile iş ilişkisine girilip girilmeyeceğine dair kararlarında söz konusu raporlarda yer alan tespit ve değerlendirmeler önemli rol almaktadır. Bu çerçevede, çalışmamızın bu bölümünde öncelikle FATF'ın, kuruluş amacı ve fonksiyonları belirtilmiş, daha sonra hazırladığı döküman ve 
raporların ülke ve finansal sektör açısından önemine ve gerekli uyum sağlanmadığı takdirde karşılaşılabilecek risklere yer verilmiştir.

\subsection{FATF (Financial Action Task Force-Mali Eylem Görev Gücü) Kuruluşu ve Uluslararası Alandaki İşlevleri}

Karaparanın aklanması ve terörizmin finansmanını önlemek için uluslararası işbirliği büyük önem taşımaktadır. Küreselleşmeyle birlikte finansal piyasaların bütünleşmesi söz konusu işbirliği ihtiyacını artırmıştır (Yahşi, 1998). Bu kapsamda FATF, OECD bünyesinde G-72 ülkelerinin 1989 yılında Paris'te devlet veya hükümet başkanlıkları seviyesinde yaptıkları toplantıda uluslararası alanda karapara aklamaya karşı etkin mücadele ve işbirliğinin gerçekleştirilmesi amaciyla kurulmuştur. FATF, Türkiye'nin3 de dahil olduğu 34 üye devlet ve 2 üye bölgesel kuruluş ile uluslararası bir kuruluş olarak ortaya çıkmaktadır. (FATF, 2013a). Kuruluş amacı itibarıyla (Üstün, 2005:10);

- Karapara aklama tehlikesine karşı bütün dünyaya mesaj vermek ve bu kapsamda, FATF üyeliğinin genişlemesine dayalı olarak dünya çapında aklamaya karşı girişimleri desteklemek,

- Karapara aklamaya karşı yasal, finansal, operasyonel ve uluslararası konularda tedbirler alınması için yayınladığı 40 Tavsiyenin üye ülkelerce uygulanmasını takip etmek ve değerlendirmek,

- Karapara aklama teknik ve trendlerine karşı tedbirler ve stratejiler geliştirmek

gibi üç tür misyon üstlenen FATF, karapara aklama ile mücadele standartlarını ortaya koyan 40 Tavsiye Kararını ilk defa 1990 yılında yayınlamış ve daha sonra bu tavsiye kararlarını bazı değişikliklerle yenileyerek 1996 yılında tekrar yayınlama yoluna gitmiştir. 11 Eylül 2001 tarihinde ABD'de meydana gelen olayların, terörist eylemlerle birlikte terörizmin finansmanının önlenmesi konusunu ön plana çıkarması üzerine, 29-30 Ekim 2001 tarihlerinde Washington D.C.'de yapılan FATF olağanüstü toplantısında, FATF'ın karapara aklama ile mücadele misyonuna terörizmin finansmanın önlenmesi de eklenmiş ve bu amaçla hazırlanan 8 Özel Tavsiye 31 Ekim 2001 tarihinde yayınlanmıştır. Yeni 40 Tavsiye ve terörizmin finansmanının önlenmesi konusundaki 8 Özel Tavsiye, karapara aklama ve terörizmin finansmanı ile mücadelenin ortak temelini oluşturmuştur. FATF, 22 Ekim 2004 tarihindeki Genel Kurul toplantısında terörizmin finansmanı konusunda 1 özel tavsiye daha yayınlamış olup, böylece özel tavsiyelerin sayısı 9'a ulaşmıştır (Üstün, 2005:10). FATF, üye ülkeleri, karapara aklama ve terörizmin finansmanının önlenmesi konusunda gösterdiği gelişmeler bakımından periyodik olarak denetlemekte ve değerlendirmektedir.

FATF tarafından geliştirilen mevzuat etkili bir takip sistemi ile desteklenmektedir. FATF ve FATF benzeri organların üyeleri düzenli değerlendirmeye tabi tutulmakta olup, değerlendirme sonucunda karşılıklı değerlendirme raporları hazırlanmaktadır. FATF, üyesi

\footnotetext{
${ }^{2} \mathrm{G} 7$ ülkeleri ABD, İtalya, Fransa, İngiltere, Japonya, Kanada ve Almanya’dan oluşmaktadır.

${ }^{3}$ Türkiye FATF'a 1991 yılından beri üyedir (Üstün, 2005:27) .
} 
olmasa bile suç gelirlerinin aklanması ve terörün finansmanının önlenmesi konusunda yayınlanmış olan "standartlara uygun hareket etmeyen ülkeler" veya "bölgelerle" ilgili tedbir alınmasını sağlayacak bir mekanizma kurmuştur. Söz konusu kuruluş bu kapsamda yapmış olduğu çalışmalar neticesinde belirlediği standartlara uymayan ülkeleri "İşbirliği Yapmayan Ülke veya Bölgeler (Non-Cooperative Countries or Territories: NCCT) listesinde periyodik olarak açıklamaktadır. Mevcut ekonomik ve finansal yapıda ülkelere karşı tedbir uygulanması o ülkeler için hem maddi hem de itibari risk anlamına gelmektedir. Bu sebeple "İşbirliği Yapmayan Ülke veya Bölgeler Listesinde” yer alan ülkeler listeden çıkabilmek için yasal ve kurumsal yapı oluşturmaya, kurdukları bu yapının etkinliğini artırmaya çalışmaktadırlar (Sinkaya ve Yıldırım, 2010:41). FATF'ın yasal yaptırım gücü bulunmasa da değerlendirme metodolojisi esas alınarak yapılan üye ülke inceleme ve değerlendirmeleri uluslararası finans çevreleri ile IMF ve Dünya Bankası gibi çoğu uluslararası kuruluşlar tarafından sıkı bir şekilde değerlendirilmekte ve takip edilmektedir (Doğan, 2013). Finansal kuruluşlar, FATF tavsiyelerini uygulamayan ya da eksik uygulayan ve bu nedenle FATF'ın İşbirliği Yapmayan Ülke Listesi'nde yer alan ülkelerin vatandaşları, şirketleri ve finansal kuruluşları ile girecekleri iş ilişkilerine ve işlemlere özel dikkat göstermeleri ve gerekli tedbirleri almalıdırlar (Çakır, 2006:46). Aksi takdirde, uluslararası finansal sistem içindeki varlıkları tehlikeye girer ve ülke ve finansal sistemlerinin küresel entegrasyonu zayıflar.

FATF tarafından iki ana kategoride yılda üç kez olmak üzere işbirliği yapmayan bölge veya ülkeler listesine ilişkin dökümanlar yayınlanmaktadır. Bunlardan biri 'FATF Kamuoyu Açıklaması'dır (Public Statement) (FATF, 2014a): FATF Kamuoyu Açıklamasında (FATF, 2014a);

- Karaparanın aklanmasının ve terörizmin finansmanının önlenmesinde stratejik eksiklikleri olan ve bunlara karşı tedbir uygulanması gereken ülke veya bölgeler ile,

- Belirtilen eksikliklerde yeteri derecede ilerleme sağlamayan ya da eksiklikleri gidermek için FATF ile geliştirilen bir eylem planı taahhüt etmeyen ülke veya bölgeler tanımlanır.

FATF tarafından yayınlanan diğer kamuoyu açıklaması ise "Karaparanın Aklanması ve Terörizmin Finansmanının Önlenmesine ilişkin Uyumun Geliştirilmesi: Devam Eden Süreç" (Improving Global AML/CFT4 Compliance: On-going Process) adlı dökümandır. Bu dökümanda FATF'ın karaparanın aklanması ve terörizmin finansmanının önlenmesi konusunda stratejik eksiklikleri olan ve bunların giderilmesi için kendisiyle birlikte üst düzey politik taahhütle eylem planı geliştiren ülkeler tanımlanır. Her ülkenin karaparanın aklanması ve terörizmin finansmanı hususlarında karşılaştı̆̆ı riskler birbirinden farklı olduğu için durumları ve eylem planları da farklılık taşır (FATF, 2014a).

FATF söz konusu dökümanlarda yayınladığı ülkeleri, gerçekleştirdikleri gelişim ve ilerlemeleri tespit etmek amaciyla izleme sürecine (Monitoring of Progress) alır ve yeterli

\footnotetext{
${ }^{4}$ AML/CFT kısaltmalarından AML (antimoney laundering), "karaparanın aklanmasının önlenmesi”, CFT, (combating the financing terrorism) "terörizmin finansmanı ile mücadele" anlamlarına karşıllık gelir.
} 
ilerleme sağlanıp "Kamuoyu Açıklamaları”na ilişkin yayınlardan çıkarılana kadar bu ülkelerle eylem planlarının uygulanması ve eksiklerin giderilmesi için çalışmalar yapar. Buna ilaveten, FATF, uluslararası finansal sistemde karaparanın aklanması veya terörizmin finansmanı hususlarında risk yaratabilecek ülke ve bölgelerin belirlenmesi amacıyla çalışmalar gerçekleştirir (FATF, 2014a).

Aynı zamanda, uluslararası finans, ticaret ve diplomatik çevrelerde, stratejik eksiklikleri olan ve bunlara karşı tedbir uygulanması gereken ülke listesi "kara liste" (black list), FATF'ın belirttiği eksikliklerde yeterli derecede ilerleme sağlamayan ya da eksiklikleri gidermek için FATF ile birlikte bir eylem planı geliştirmeyen ve taahhüt etmeyen ülke listesi "koyu gri liste" (dark grey list), FATF'ın karaparanın aklanması ve terörizmin finansmanının önlenmesi konusunda stratejik eksiklikleri olan ve bunların giderilmesi için kendisiyle birlikte üst düzey politik taahhütle eylem planı geliştiren ülkelerin bulunduğu liste ise "gri liste" (grey list) şeklinde kategorize edilerek sınıflandırılmaktadır (FATF Watch, 2013).

\subsection{Karaparanın Aklanması ve Terörizmin Finansmanının Önlenmesine İlişkin FATF Tarafından Yüksek Riskli ve İşbirliği Yapmayan Ülkeler Hakkında Yakın Dönemde Yayınlanan Dökümanların Değerlendirilmesi}

Aşağıda yer alan Tablo 1 ve Tablo 2'de FATF tarafından yüksek riskli ve işbirliği yapmayan ülkeler hakkında yakın dönemde yayınlanan kamuoyu açıklamalarına ilişkin raporlar dikkate alınarak ülkelerin kronolojik gelişimi gösterilmiştir. Söz konusu tablolardan Tablo 1, FATF tarafından yüksek riskli ve işbirliği yapmadığı kabul edilen ülkelerden risk derecesi diğerlerine göre daha yüksek olan ve karşı tedbir uygulanması gereken ülkeleri kapsamaktadır. Tablo 2'de FATF ile tespit edilen eksiklikleri giderme konusunda gönüllü olarak işbirliği yapan ve izleme sürecinde yer alan ülkeler bulunmaktadır. FATF tarafından Haziran/2014 döneminde yayınlanan yüksek riskli ve işbirliği yapmayan ülkeler hakkında hazırlanan raporlar çerçevesinde yapılan kamuoyu açıklamaları dikkate alınarak her üç listenin (kara liste, koyu gri liste, gri liste) birlikte bulunduğu ve buna göre sinıflandırılan ülkeler ise Tablo 3'de sunulmaktadır. Tablo 3 FATF'ın yaptığı son kamuoyu açıklamasına göre hazırlanan ve ülkelerin bulunduğu kategoriyi gösteren en güncel bilgileri yansıtmaktadır.

FATF'ın yukanda ifade edilen çerçevede yaptığı incelemeler sonucunda "Kamuoyu Açıklamaları"nda eksiklikliklerini belirterek sinıflandırdığı ülkelerin Şubat/2010 ve Şubat/2014 dönemleri arasındaki kronolojik gelişimini gösteren listeler Tablo 1'de sunulmuştur. İşbirliği yapmayan ve karşı tedbir alınması gereken ülkeler "kara liste", FATF'ın belirttiği eksikliklerde yeterli derecede ilerleme sağlamayan ya da eksiklikleri gidermek için FATF ile birlikte bir eylem planı geliştirmeyen ve taahhüt etmeyen ülkeler "koyu gri liste" başlıkları altında sınıflandırılmıştır.

Tablo 1 ve Tablo 3 birlikte incelendiğinde, İran ve Kore Demokratik Halk Cumhuriyeti'nin (Kuzey Kore) AML/CFT politikalarının yetersizliği nedeniyle stratejik eksiklikleri olan ve işbirliği yapmayan ülkeler listesinde, karşı tedbir alınması gereken ülkeler olarak yer aldıkları görülmektedir. Bu ülkeler FATF'ın tavsiyeleri doğrultusunda işbirliğine 
hiçbir şekilde yanaşmadığından, karşı tedbirlerin en üst düzeyde uygulanması gereken ülkelerdir. Söz konusu ülkelerden İran Şubat/2009, Kuzey Kore ise Şubat/2011 tarihinde "kara liste" olarak tabir edilen karşı tedbirlerin en üst düzeyde uygulanması gereken ülke listesine alınmışlardır (FATF, 2014a). Dikkat edileceği üzere kronolojik olarak her iki ülke günümüze kadar karşı tedbir alınması gereken ülkeler listesinde kalmıştır.

Bu kapsamda, İran'ın son dönemde uluslararası kuruluşlar nezdindeki durumunu göz önünde bulundurmak gerekmektedir. İran son yıllarda nükleer programının öne çıkması nedeniyle BM Güvenlik Konseyi tarafından alınan kararlar gereği bazı ekonomik ve mali yaptırımlara muhataptır. Yaptırımların bir bölümü İran'ın nükleer faaliyetlerinin barışçıl olmaması iddiasına dayandırılırken, önemli bir kısmı da İran'ın terörizmi desteklediği iddialarına dayandırılmaktadır. 11 Eylül 2001'den sonra uluslararası alanda terörizmin finansmanının önlenmesine yönelik artan işbirliği çerçevesinde FATF, İran’1 bu konuda yeterli işbirliği yapmamakla suçlamakta ve para aklama ve terörizmin finans kaynaklarının önlenmesi sisteminin yetersizliklerinden dolayı ortaya çıkan risklere dikkat çekmektedir (Sinkaya ve Yıldırım, 2010).

FATF (2014b, 2014c), İran ile ilgili yaptığı son iki dönemdeki değerlendirmede, İran'ın özellikle terörizmin finansmanı konusunda gerekli tedbirleri almadığını ve bu ülkeyi uluslararası finansal sistem için risk ve tehdit olarak gördüğünü vurgulayarak üyelerine ve diğer ülkelere 25 Şubat 2009 tarihinde yaptığı çağrıyı ${ }^{5}$ yinelemiştir. FATF İran'ın AML/CFT ile ilgili eksikliklerini ivedi olarak gidermesi ve bu konuda uygulamalar geliştirmesi için adım atması gerektiğini belirtmektedir. Aksi takdirde FATF (2014c), yapacağı uluslararası çalışmalar ve istişareler çerçevesinde Ekim/2014 tarihinden itibaren daha da güçlendirilmiş tedbirlerin alınmasına başlanacağını ifade ederek İran'ı uyarmıştır (FAFT, 2014c:2).

\footnotetext{
5 Söz konusu çağrıda FATF, İran'ın AML/CFT rejiminin uluslararası finansal sistem için tehlike oluşturduğundan bahisle tüm ülkelere ve finansal kuruluşlara, İran, burada bulunan finansal kuruluşlar ve şirketler ile girecekleri ilişkide dikkatli hareket etmeleri ve özen göstermeleri konusunda çağrıda bulunmuştur. Ayrıca, İran ile girilecek muhabir banka ilişkilerinde alınan risk azaltım tedbirlerinin by-pass edilmesine ya da alınan tedbirlerden kaçınılmasına yönelik girişimlere karşı dikkatli olunması konusunda ikazda bulunulmuştur (FATF, 2009).
} 
Tablo 1. FATF İşbirliği Yapmayan Ülke veya Bölgeler Listesinin (NCCT) İlk İki Kademesinde (Kara ve Koyu Gri Liste*) Yer Alan Ülkeler ve Türkiye'nin Kronolojik Gelişimi

\begin{tabular}{|c|c|c|c|c|c|c|c|c|c|c|c|c|c|c|c|c|c|}
\hline \multicolumn{2}{|c|}{ Şubat 2010} & \multicolumn{2}{|c|}{ Haziran 2010} & \multicolumn{2}{|c|}{ Şubat 2011} & \multicolumn{2}{|c|}{ Haziran 2011} & \multicolumn{2}{|c|}{ Şubat 2012} & \multicolumn{2}{|c|}{ Haziran 2012} & \multicolumn{2}{|c|}{ Şubat 2013} & \multicolumn{2}{|c|}{ Haziran 2013} & \multicolumn{2}{|c|}{ Şubat 2014} \\
\hline Kara Liste & Koyu Gri Liste & Kara Liste & Koyu Gri Liste & Kara Liste & Koyu Gri Liste & Kara Liste & Koyu Gri Liste & Kara Liste & Koyu Gri Liste & Kara Liste & Koyu Gri Liste & Kara Liste & Koyu Gri Liste & Kara Liste & Koyu Gri Liste & Kara Liste & Koyu Gri Liste \\
\hline İran & \begin{tabular}{|l} 
Angola \\
Kuzey Kore \\
Ekvator \\
Etiyopya \\
Pakistan \\
Türkmenistan \\
Sao Tome\& \\
Principe
\end{tabular} & İran & $\begin{array}{l}\text { Kuzey Kore } \\
\text { Sao Tome\& } \\
\text { Principe }\end{array}$ & $\begin{array}{l}\text { İran } \\
\text { Kuzey Kore }\end{array}$ & - & $\begin{array}{l}\text { İran } \\
\text { Kuzey Kore }\end{array}$ & \begin{tabular}{|l} 
Bolivya \\
Küba \\
Etiyopya \\
Kenya \\
Myanmar \\
Sri Lanka \\
Suriye \\
Türkiye
\end{tabular} & $\begin{array}{l}\text { İran } \\
\text { Kuzey Kore }\end{array}$ & \begin{tabular}{|l} 
Küba \\
Bolivya \\
Etiyopya \\
Gana \\
Endonezya \\
Kenya \\
Myanmar \\
Nijerya \\
Pakistan \\
Sri Lanka \\
Suriye \\
Tanzanya \\
Tayland \\
Türkiye \\
Sao Tome\& \\
Principe
\end{tabular} & $\begin{array}{l}\text { İran } \\
\text { Kuzey Kore }\end{array}$ & $\begin{array}{l}\text { Bolivya } \\
\text { Küba } \\
\text { Ekvator } \\
\text { Etiyopya } \\
\text { Gana } \\
\text { Endonezya } \\
\text { Kenya } \\
\text { Myanmar } \\
\text { Nijerya } \\
\text { Pakistan } \\
\text { Sri Lanka } \\
\text { Suriye } \\
\text { Tanzanya } \\
\text { Tayland } \\
\text { Türkiye } \\
\text { Vietnam } \\
\text { Yemen } \\
\text { Sao Tome\& } \\
\text { Principe }\end{array}$ & $\begin{array}{l}\text { İran } \\
\text { Kuzey Kore }\end{array}$ & \begin{tabular}{|l} 
Ekvator \\
Etiyopya \\
Endonezya \\
Kenya \\
Myanmar \\
Nijerya \\
Pakistan \\
Suriye \\
Tanzanya \\
Türkiye \\
Vietnam \\
Yemen \\
Sao Tome\& \\
Principe
\end{tabular} & \begin{tabular}{|l|} 
Iran \\
Kuzey Kore
\end{tabular} & \begin{tabular}{|l} 
Ekvator \\
Etiyopya \\
Endonezya \\
Kenya \\
Myanmar \\
Pakistan \\
Suriye \\
Tanzanya \\
Türkiye \\
Vietnam \\
Yemen \\
Sao Tome\& \\
Principe
\end{tabular} & $\begin{array}{l}\text { Iran } \\
\text { Kuzey Kore }\end{array}$ & \begin{tabular}{|l|} 
Cezayir \\
Ekvator \\
Etiyopya \\
Endonezya \\
Myanmar \\
Pakistan \\
Suriye \\
Türkiye \\
Yemen
\end{tabular} \\
\hline
\end{tabular}

* Kara liste "FATF’n stratejik eksiklikleri olduğunu tespit ettiği ve karşı tedbir uygulanması gereken ülkelere ilişkin listeyi", koyu gri liste "FATFın belirttiği eksikliklerde yeterli derecede ilerleme sağlamayan ve işbirliği yapmayan ülkelere ilişkin listeyi" ifade eder. Kaynak: FATF (2010a, 2010b, 2011a, 201 lb, 2012a, 2012b, 2013b, 2013c, 2014b) 
FATF açıklamalarında İran ile aynı kategoride yer alan Kuzey Kore'nin durumu da bu ülke ile benzer özellikler taşımaktadır. Kuzey Kore ile ilgili yaptığı son iki dönemdeki açıklamada FATF (2014b, 2014c), Kuzey Kore'nin AML/CFT rejiminde önemli eksiklikleri bulunduğunu ve uluslararası finansal sistemin ihtiyaçlarına cevap verebilecek şekilde herhangi bir ilerleme sağlamadığını belirterek, bu durumun uluslararası finansal sistemi tehdit ettiğini belirtmektedir. FATF 25 Şubat 2011 tarihinde yaptığı çağrıyı6 yineleyerek üyelerini ve diğer ülkeleri, gerek Kuzey Kore gerekse burada bulunan finansal kuruluşlar ve şirketlerle kuracakları iş ilişkileri ve yapacakları işlemleri özenle incelemeleri ve dikkatle gözden geçirmeleri konusunda uyarmaktadır (FATF, 2014c:2). Dikkat edileceği üzere kara listede yer alan ülkeler küresel konjonktürde uluslararası alanda sorunları bulunan dışlanmış ve Birleşmiş Milletler tarafından haklarında tedbir kararları alınan ülkelerdir.

Birçok dönem koyu gri listede yer alan ülkelerin çoğu ise az gelişmiş ülke olup, bazıları gelişmekte olan ülkelerdir. Bu ülkelerden Etiyopya, Pakistan ve Ekvator gibi ülkeler az gelişmiş alt gelir grubu ülkelerdir. Myanmar ve Suriye gibi ülkeler ise kendi içlerinde siyasi kargaşa ve karışıklıklar yaşayan ülkelerdir. Esasen bu ülkelerin çoğunun siyasi açıdan istikrarsız yapıya sahip olması ve aynı zamanda ekonomik gelişim seviyelerinin yeterli düzeyde olmamasına ilişkin faktörlerin, karaparanın aklanması ve terörizmin finansmanı girişimlerine uygun zemin hazırladığı ve söz konusu faaliyetler için rahat hareket alanı yarattığı izlenimi edinilmektedir.

FATF ile tespit edilen eksiklikleri giderme konusunda gönüllü olarak işbirliği yapan ve Şubat/2010 ile Şubat/2014 dönemleri arasında izleme sürecinde yer alan ülkelerin bulunduğu listeler Tablo 2'de sunulmuştur. Dikkat edileceği üzere diğer listelere göre daha 1lımlı seviyede olan ve gri liste olarak tabir edilen bu listelerde de az gelişmiş ve gelişmekte olan ülkeler yer almaktadır. Söz konusu ülkeler arasında Arjantin ve Türkiye gibi gelişmekte olan ülkeler bulunduğu gibi özellikle uluslararası finansal mimariye yeni uyum sağlayan çoğu Afrika ülkesi ile Kırgızistan, Tacikistan, Arnavutluk gibi geçiş ekonomisi ülkelerinin de bulunduğu göze çarpmaktadır. Bu ülkelerden FATF'ın istediği değişiklikleri yapan ve uygulamaları geliştiren ülkeler izlenmesine gerek kalmayan ülke kategorisine alınarak bu durum kamuoyu ile paylaşılmaktadır.

\footnotetext{
${ }^{6}$ Söz konusu çağrıda FATF, Kuzey Kore'nin AML/CFT rejiminin uluslararası finansal sistem için tehlike oluşturduğundan bahisle derhal anlamlı düzenlemeler yapması konusunda bu ülkeye uyarıda bulunmuştur. Ayrıca tüm ülkelere ve finansal kuruluşlara, Kuzey Kore, burada bulunan finansal kuruluşlar ve şirketler ile girecekleri ilişkide dikkatli hareket etmeleri ve özen göstermeleri konusunda çağrı yapılmıştır. Buna ilaveten, Kuzey Kore ile girilecek muhabir banka ilişkilerinde alınan risk azaltım tedbirlerinin by-pass edilmesine ya da alınan tedbirlerden kaçınılmasına yönelik girişimlere karşı dikkatli olunması konusunda ikazda bulunulmuştur. FATF, AML/CFT rejimindeki eksikliklerinin giderilmesi için Kuzey Kore'ye her zaman yardıma hazır olduğunu belirtmiştir (FATF, 2011a).
} 
The Journal of Accounting and Finance

October/ 2014

Tablo 2. FATF İșbirliği Yapmayan Ülke veya Bölgeler Listesinin (NCCT) Üçüncü Kademesinde (Gri Liste*) Yer Alan Ülkelerin Yakın Dönemdeki Kronolojik Gelişimi

\begin{tabular}{|c|c|c|c|c|c|c|c|c|c|c|c|c|c|c|}
\hline \multicolumn{3}{|c|}{ Şubat 2010} & \multicolumn{3}{|c|}{ Şubat 2011} & \multicolumn{3}{|c|}{ Şubat 2012} & \multicolumn{3}{|c|}{ Şubat 2013} & \multicolumn{3}{|c|}{ Şubat 2014} \\
\hline \begin{tabular}{|l|} 
Karaparanın \\
Aklanmasunn ve \\
Terörizmin \\
Finansmanının \\
Önlenmesine ilişkin \\
Uyumun Geliştirilmesi: \\
Devam Eden İleme \\
Süreci
\end{tabular} & \begin{tabular}{|l|} 
izleme \\
Sürecinde \\
Yeterli \\
ilerreme \\
Sağlamayan \\
Ükkeler
\end{tabular} & \begin{tabular}{|l} 
İlenmesine \\
Gerek \\
Kalmayan \\
ülkeler \\
\end{tabular} & \begin{tabular}{|l|} 
Karaparanın \\
Aklanmassnnn ve \\
Terörizmin \\
Finansmanının \\
Önlenmesine ilişkin \\
Uyumun Gelistirilmesi: \\
Devam Eden İleme \\
Süreci
\end{tabular} & \begin{tabular}{|l|} 
İzleme \\
Sürecinde \\
Yeterli \\
Illerleme \\
Sağlamayan \\
Ülkeler
\end{tabular} & \begin{tabular}{|l} 
İlenmesine \\
Gerek \\
Kalmayan \\
ülkeler
\end{tabular} & \begin{tabular}{|l|} 
Karaparanın \\
Aklanmasinn ve \\
Terörizmin \\
Finansmanının \\
Önlenmesine ilişkin \\
Uyumun Geliștirilmesi: \\
Devam Eden İzleme \\
Süreci
\end{tabular} & \begin{tabular}{|l|} 
İleme \\
Sürecinde \\
Yeterli \\
illerleme \\
Sağlamayan \\
Ülkeler \\
\end{tabular} & \begin{tabular}{|l|} 
İlenmesine \\
Gerek \\
Kalmayan \\
ülkeler
\end{tabular} & \begin{tabular}{|l|} 
Karaparanın \\
Aklanmassmın ve \\
Terörizmin \\
Finansmaninın \\
Önlenmesine ilişkin \\
Uyumun Geliștirilmesi: \\
Devam Eden İleme \\
Süreci
\end{tabular} & \begin{tabular}{|l|l|} 
İzleme \\
Sürecinde \\
Yeterli \\
ilerleme \\
Sağlamayan \\
Ülkeler \\
\end{tabular} & \begin{tabular}{|l|} 
İlenmesine \\
Gerek \\
Kalmayan \\
Ülkeler
\end{tabular} & \begin{tabular}{|l|} 
Karaparanın \\
Aklanmassnın ve \\
Terörizmin \\
Finansmanının \\
Önlenmesine ilişkin \\
Uyumun Geliştirilmesi: \\
Devam Eden İleme \\
Süreci
\end{tabular} & \begin{tabular}{|l|} 
izleme \\
Sürecinde \\
Yeterli \\
ilerreme \\
Sağglamayan \\
Ükeler \\
\end{tabular} & \begin{tabular}{|l|} 
İlenmesine \\
Gerek \\
Kalmayan \\
Ülkeler
\end{tabular} \\
\hline \begin{tabular}{|l} 
Antigua ve Barbuda \\
Azerbaycan \\
Bolivya \\
Yunanistan \\
Endonezya \\
Kenya \\
Fas \\
Myanmar \\
Nepal \\
Nijerya \\
Paraguay \\
Katar \\
Sri Lanka \\
Sudan \\
Suriye \\
Trinidad ve Tobago \\
Tayland \\
Türkiye \\
Ukrayna \\
Yemen
\end{tabular} & - & - & \begin{tabular}{|l} 
Antigua ve Barbuda \\
Bangladeş \\
Ekvator \\
Gana \\
Yunanistan \\
Brunei Darusselam \\
Honduras \\
Endonezya \\
Fas \\
Pakistan \\
Paraguay \\
Filipinler \\
Sao Tome ve Principe \\
Sudan \\
Tanzanya \\
Tayland \\
Türkmenistan \\
Ukrayna \\
Venezuela \\
Vietnam \\
Yemen
\end{tabular} & \begin{tabular}{|l|} 
Angola \\
Bolivya \\
Etiyopya \\
Kenya \\
Myanmar \\
Nepal \\
Nijerya \\
Sri Lanka \\
Suriye \\
Trinidad ve \\
Tobago \\
Türkiye
\end{tabular} & - & \begin{tabular}{|l} 
Cezayir \\
Angola \\
Antigua ve Barbuda \\
Arjantin \\
Banglades \\
Brunei Darusselam \\
Kambodya \\
Honduras \\
Paraguay \\
Krrgzistan \\
Moğolistan \\
Fas \\
Namibya \\
Nepal \\
Nikaragua \\
Sudan \\
Tacikistan \\
Trinidad veTobago \\
Türkmenistan \\
Venezuela \\
Zimbabve
\end{tabular} & \begin{tabular}{|l} 
Ekvator \\
Vietnam \\
Filipinler \\
Yemen
\end{tabular} & - & \begin{tabular}{|l} 
Afganistan \\
Arnavutluk \\
Cezayir \\
Angola \\
Antigua ve Barbuda \\
Arjantin \\
Banglades \\
Bolivya \\
Brunei Darusselam \\
Kambodya \\
Küba \\
Kuveyt \\
Krgrzistan \\
Mongolya \\
Namibya \\
Nepal \\
Nikaragua \\
Filipinler \\
Sri Lanka \\
Sudan \\
Tayland \\
Zimbabve \\
\end{tabular} & \begin{tabular}{|l|} 
Fas \\
Tacikistan
\end{tabular} & \begin{tabular}{|l|} 
Gana \\
Venezualla
\end{tabular} & \begin{tabular}{|l} 
Arnavutluk \\
Angola \\
Arjantin \\
Küba \\
Irak \\
Kenya \\
Kuveyt \\
Krggzistan \\
Lao PDR \\
Moğolistan \\
Namibya \\
Nepal \\
Nikaragua \\
Papua Yeni Gine \\
Sudan \\
Tacikistan \\
Tanzanya \\
Uganda \\
Zimbabve
\end{tabular} & \begin{tabular}{|l|} 
Afganistan \\
Kambodya
\end{tabular} & \begin{tabular}{|l} 
Bangladeş \\
Vietnam \\
Antigua ve \\
Barbuda
\end{tabular} \\
\hline
\end{tabular}

* Gri liste, "karaparanın aklanmasııın ve terörizmin finansmanını önlenmesine ilişkin uyumun geliştirimesi: devameden izleme sürecinde yer alan ülkelerin bulunduğu listeyi" ifade eder.

Kaynak: FATF (2010c, 2011c, 2012c, 2013d, 2014d) 
Şubat/2014 döneminde Tablo 1'de yer aldığg üzere koyu gri listede yer alan Etiyopya, Pakistan, Suriye, Türkiye ve Yemen, FATF ile tespit edilen eksiklikleri giderme konusunda gönüllü olarak işbirliği yaptıkları için FATF'ın Haziran/2014 döneminde yaptığı toplantı neticesinde Tablo 3'de de görüldüğü gibi diğerlerine göre daha ılımlı bir liste olan gri listeye aktarılmışlardır (FATF, 2014d).

Tablo 3. FATF'nn Haziran/2014 Dönemi İtibarıyla Yayınladığı İşbirliği Yapmayan Ülke veya Bölgeler Listesi (NCCT)

\begin{tabular}{|c|c|c|c|}
\hline $\begin{array}{l}\text { Stratejik eksiklikleri olan } \\
\text { ve karşı tedbir } \\
\text { uygulanması gereken } \\
\text { ülkeler (Kara Liste) }\end{array}$ & $\begin{array}{l}\text { FATF'ın belirttiği } \\
\text { eksikliklerde yeterli derecede } \\
\text { ilerleme sağlamayan ve } \\
\text { işbirliği yapmayan ülkeler }\end{array}$ & \multicolumn{2}{|c|}{$\begin{array}{l}\text { Karaparanın Aklanması ve Terörizmin Finansmanının } \\
\text { Önlenmesine ilişkin Uyumun Geliş tirilmesi: Devam } \\
\text { Eden İzleme Süreci (Gri Liste) }\end{array}$} \\
\hline İran & Cezayir & Afganistan & Sudan \\
\hline \multirow[t]{14}{*}{ Kuzey Kore } & Ekvator & Arnavutluk & Suriye \\
\hline & Endonezya & Angola & Tacikistan \\
\hline & Myanmar & Arjantin & Türkiye \\
\hline & & Kambodya & Uganda \\
\hline & & Küba & Yemen \\
\hline & & Etiyopya & Zimbabve \\
\hline & & Irak & İzlenmesine Gerek Kalmayan Ülkeler \\
\hline & & Kuveyt & Kenya \\
\hline & & Lao PDR & Moğolistan \\
\hline & & Namibya & Tanzanya \\
\hline & & Nikaragua & Kırgizistan \\
\hline & & Pakistan & Nepal \\
\hline & & Panama & $\begin{array}{l}\text { İzleme Sürecinde Yeterli İlerleme } \\
\text { Sağlamayan Ülkeler }\end{array}$ \\
\hline & & Papua Yeni Gine & - \\
\hline
\end{tabular}

Kaynak: FATF (2014c, 2014d)

3.3. FATF Tarafından Yakın Dönemde Yüksek Riskli ve İşbirliği Yapmayan Ülkeler Hakkında Yayınlanan Dökümanlar Çerçevesinde Türkiye'nin Karaparanın Aklanması ve Terörizmin Finansmanının Önlenmesine İlişkin Uluslararası Uyumunun Analizi

FATF'ın Türkiye için yakın dönemde yaptığı incelemeler sonucunda kamuoyu ile paylaştığı açıklamalar ve raporların içeriğinin kronolojik olarak incelenmesi, uluslararası finans çevrelerinin bu alanda Türkiye'ye bakış açılarının değerlendirilmesi ve analizi bakımından faydalı olacaktır. Tablo 1, Tablo 2 ve Tablo 3, karaparanın aklanması ve terörizmin finansmanının önlenmesi politikalarında Türkiye'nin yakın dönemde diğer ülkeler arasında bulunduğu uluslararası konumu göstermesi açısından önem arz etmektedir.

FATF'ın Türkiye hakkında yaptığı en kapsamlı çalışma Eylül/2006 döneminde Kurum yetkililerinin Türkiye'ye yaptıkları ziyaret çerçevesinde hazırlanan ve Şubat/2007 döneminde yayınlanan rapordur. Söz konusu çalışmada Türkiye'nin AML/CFT politikalarının yeterliliğinin yerinde araştırılması ve karaparanın aklanmasının önlenmesi hakkında 
Ekim/2006 döneminde yürürlüğe giren yasanın7 FATF düzenlemelerine uyumluluğunun incelenmesi amaçlanmıştır. İnceleme sonucunda, çıkan yasa çok yeni olduğu için etkinliğinin tam olarak ölçülmediğinden bahsedilmiştir. Rapor içeriğinde genel olarak Türkiye'de AML/CFT düzenlemelerinin henüz yeterince etkin bir seviyede uygulanmadığı ve gelişme aşamasında olduğuna vurgu yapılmıştır (FATF, 2007). Türkiye daha sonra FATF tarafından metodolojisi belirlenen ve yılda 3 kez yayınlanan NCCT çalışmalarında incelenmiş ve yapılan incelemelerin sonuçları uluslararası kamuoyu ile paylaşılmıştır. Türkiye NCCT listelerine ilk kez 2010 yılında aktarılmış olup, kronolojik gelişimi detayları ile aşağıda sunulmuştur.

Türkiye, Şubat 2010 döneminde FATF (2010c) ile tespit edilen eksiklikleri giderme konusunda gönüllü olarak işbirliği yapan ve izleme sürecinde yer alan ülkeler listesine (gri liste), Haziran/2011 döneminden itibaren ise FATF (2011b) tarafından işbirliği yapmayan ülke ve bölgeler listesine (koyu gri liste) alınmış ve bu tarihten Haziran/2014 dönemine kadar söz konusu listenin dışına çıkmamıştır. Belirtilen dönemler arasında yayınlanan dökümanlarda, Türkiye'nin terörist varlıkların tanımlanması ve dondurulması konusunda yetersizlikleri olduğuna dair tespitler yer almıştır. FATF, geçen süre zarfında yayınladığı dökümanlarda da benzer tespitlere yer vermiştir.

FATF, Haziran/2012 döneminde Türkiye ile ilgili yaptığı açıklamasını öncekilere göre sertleştirmiş̧ir. FATF açıklamasında Türkiye'nin stratejik eksikliklerini gidermesi için siyasi çabalarına rağmen, eylem planının uygulanmasında eksik kaldığını ve belirli alanlarda eksikliklerinin devam ettiğini vurgulamıştır (Doğan, 2013:14). FATF ayrıca, Türkiye'nin terörizmin finansmanının önlenmesine ilişkin eksikliklerini Ekim/2012 dönemine kadar gidermediği takdirde sahip olduğu riskleri ile orantılı tedbirlerin uygulanması için üyelerine çağrıda bulunacağını duyurmuştur (FATF, 2012b).

Ekim/2012 döneminde ise FATF yaptığ incelemeler sonucunda Türkiye'nin mevcut eksikliklerini giderecek düzenlemeleri yapmadığını tespit etmiş ve bu nedenle 22 Şubat 2013 tarihine kadar gerekli düzenlemeleri yapmadığı takdirde Türkiye'nin üyeliğinin askıya alınacağını ve üyeleri ve diğer ülkelere, Türkiye'nin sahip olduğu risklere karşı ek tedbirler almaları konusunda çağrıda bulunmuştur (FATF, 2012d). Türkiye, anılan rapor tarihi itibarıyla Endonezya, Pakistan, Yemen, Gana ve Nijerya gibi ülkelerin bulunduğu listede yer almıştır (Doğan, 2013:14).

20-22 Şubat 2013 tarihinde FATF olağan Genel Kurul toplantılarında yapılan değerlendirmede ise Türkiye'nin 15 Şubat 2013 tarihinde yukarıda bahsedilen eksiklikleri ile ilgili yaptığı yasal düzenlemeler memnuniyetle karşılanmış ve üyeliğinin askıya alınmasından vazgeçildiğine dair açıklama yapılmıştır. Bununla birlikte Türkiye'nin terörizmin finansmanın önlenmesi ile ilgili hala eksiklikleri bulunduğu vurgulanmış ve bu eksikliklerin giderilmesi için Haziran/2013 tarihine kadar Türkiye'ye süre tanınmıştır (FATF, 2013d, 2013e).

21 Haziran 2013 tarihinde FATF Türkiye ile ilgili yaptığı değerlendirmede, Türkiye'nin 15 Şubat 2013 tarihinde terörizmin finansmanının önlenmesine yönelik çıkardığ yasayı ve bu yasaya istinaden daha sonra uygulamaya dönük olarak yönetmelik yayınlamasını

\footnotetext{
${ }^{7}$ Söz konusu yasa 18.10.2006 tarihinde yürürlüğe giren “Suç Gelirlerinin Aklanmasının Önlenmesi Hakkındaki” 5549 sayılı yasadır.
} 
memnuniyetle karşılamıştır. Ancak FATF, yapılan düzenlemeleri henüz Türkiye'nin terörün finansmanına karşı uyguladığı rejimi içinde engelleyici seviyede bulmamış ve konu hakkında kaygılarını dile getirmiştir (FATF, 2013c). FATF 18 Ekim 2013 tarihinde yaptı ğı açıklamada ise Türkiye'nin mevcut durumunda bir değiş̧iklik olmadığını teyit etmiştir (FATF, 2013f).

2014 yılına gelindiğinde, 2013 yılında terörizmin finansmanının önlenmesi ile ilgili FATF'ın talep ettiği düzenlemeleri yasalaştıran ve yürürlüğe alan Türkiye hakkında yapılacak değerlendirmeler uluslararası finans çevrelerince merakla beklenmiştir (Keatinge, 2014). Ancak, FATF'ın (2014b:5) işbirliği yapmayan ülke ve bölgeler hakkında Şubat/2014 döneminde yayınladığı dökümanda Türkiye yine aynı listede kalmış ve terörizmin finansmanının önlenmesi konusundaki çabaları yetersiz bulunmuştur. FATF (2014b:5) yayınladığı söz konusu dökümanda, Türkiye'ye, terörizmin finansmanının önlenmesi ve terörist varlıkların Birleşmiş Milletler Güvenlik Konseyi (UNSCR) tarafından alınan 1267 ve 1373 Sayılı Kararlar8 çerçevesinde tanımlanması ve dondurulması konularında gerekli adımları atma ve tatminkâr düzenlemeleri yapma konusunda çağrıda bulunmuştur.

Ayrıca, FATF'ın Şubat/2014 döneminde yaptığı kamuoyu açıklamasından önce gerçekleştirdiği toplantılarda Türkiye'nin, İran ve Kuzey Kore'den sonra “en riskli ülke” olduğuna dair söylemler ve spekülasyonlar Türkiye'nin uluslararası alandaki itibarına gölge düşürmüş ve zora sokmuştur. Bu durum Türk bankacılık ve finans sektörünün büyümesinin önünde engel yaratabilecek çok önemli bir husus olarak değerlendirilmiştir (Daloğlu, 2014; Keatinge, 2014).

FATF (2014d) Haziran/2014 döneminde yaptığı son kamuoyu açıklamasında Türkiye'nin terörizmin finansmanının önlenmesi ile ilgili Şubat/2010 döneminden itibaren yaptığı düzenlemeleri memnuniyetle karşılamış ve Türkiye'nin bu konuda önemli ölçüde ilerleme sağladığını ifade etmiştir. FATF, terörizmin finansmanının önlenmesi ile ilgili eksikliklerini giderecek eylem planı taahhüt eden ve terörist varlıkların tanımlanması, dondurulması ve el konulması amacıyla gerekli prosedürleri belirleyen Türkiye'nin yaptığı söz konusu düzenlemeleri yerinde ziyaret yaparak teyit edeceğini duyurmuştur (FATF, 2014d). Dikkat edileceği üzere FATF, yapacağı yerinde ziyaretle Türkiye'de gerçekleştirilen yasal düzenlemelerin gerçekte uygulanıp uygulanmadığını görmek istemektedir.

Tablo 3 incelendiğinde, "AML/CFT Politikalarında Stratejik Eksiklikleri Olan ve Karşı Tedbir Uygulanması Gereken Ülkeler" arasında İran ve Kuzey Kore; "FATF'ın

\footnotetext{
${ }^{8}$ Birleşmiş Milletler Güvenlik Konseyinin 1267 (1999) ve devamı niteliğindeki Kararları, "Taliban” ve "ElKaide" tarafından dünya genelinde gerçekleştirilen terör saldırılarının ardından bundan sonra gerçekleşmesi muhtemel terör saldırılarını engelleyebilmek ve bu örgütlenmelerin idamelerini önlemek amacıyla ilgili kişi ve kuruluşların mal varlıklarının dondurulması, bu kişilere seyahat yasağı getirilmesi, silah ambargosu uygulanması gibi yaptırımları içermektedir (MASAK, 2014).

28.09.2011 tarihinde kabul edilen, 1373 (2001) sayılı Birleşmiş Milletler Güvenlik Konseyi Kararında; terörizmin finansmanının iç hukukta ağır cezayı gerektiren bir suç olarak düzenlenmesi, terörist ve terör örgütü üyelerine ait tüm mal varlıklarının ve ekonomik kaynaklarının gecikmeksizin dondurulması, üye ülkelerin terörizmle mücadele için aralarında yoğun bir işbirliği gerçekleştirmeleri, birbirlerinden terör ve terörün finansmanıyla bağlantılı olduğunu tespit ettikleri kişi ve kuruluşların malvarlıklarının dondurulmasını talep edebilmeleri, teröristlere ve terör örgütlerine, doğrudan veya dolaylı olarak mali kaynak yaratılmasının engellenmesi hususları öngörülmüştür (MASAK, 2014).
} 
Belirttiği Eksikliklerde Yeterli Derecede İlerleme Sağlamayan ve İşbirliği Yapmayan Ülkeler" arasında Cezayir, Ekvator, Endonezya ve Myanmar adlı ülkelerin bulunduğu görülmektedir. "AML/CFT Politikalarına Uyumun Geliştirilmesine İlişkin Belirlenen Listede" ise bu konuda eksikliklerini gidermek amacıyla FATF'a üst derecede politik taahhütle eylem planı sunmuş olan aralarında Türkiye'nin de bulunduğu Afganistan, Irak, Pakistan, Suriye, Arjantin, Kuveyt ve çoğu Afrika kıtasında yer alan ülkeler bulunmaktadır. $\mathrm{Bu}$ listede izlenmesine gerek kalmayan ülkeler arasında ise Kenya, Moğolistan, Kırgızistan, Tanzanya ve Nepal yer almaktadır (FATF, 2014c, 2014d). Görüldüğü üzere AML/CFT politikalarının geliştirilmesi ve uygulanması bakımından Türkiye, az gelişmiş ve çoğu siyasi açıdan istikrarsız ülke ile aynı kategoride yer almaktadır. Bu durum, Türkiye gibi orta vadede bölgesinde finans merkezi olmayı hedefleyen bir ülkenin amaçlarıyla çelişki yaratmaktadır.

Finans merkezi olmayı hedefleyen bir ülkenin karaparanın aklanması ve terörizmin finansmanı ile ilgili riskli listelerde yer alması, uluslararası finans çevrelerinin söz konusu merkezde faaliyet gösterme kararlarını alma süreçlerinde negatif etki yaratacaktır. Aynı zamanda Türkiye'de mukim finansal kuruluşların uluslararası faaaliyetleri ve işlemleri sekteye uğrayabilecek, işlemler yoğun incelemeler sonucunda ancak gecikmeli olarak gerçekleştirilecek ya da negatif sonuçlanabilecektir. Muhabir bankacılık ilişkileri, yaşanan itibar sorununun etkisiyle yıpranacak ve dolayısıyla bankalar uluslararası alanda gösterdikleri faaliyetlerde faaliyet riski ile karşılaşabileceklerdir.

Ayrıca, Türkiye'nin sınır komşusu İran ile arasındaki ekonomik ilişkilerinin düzeyi de, bir önceki konuda bahsi geçen İran'a karşı uluslararası mali ve ekonomik yaptırımlar nedeniyle daha da önemli hale gelmektedir. Bu noktada, FATF'ın raporlarında yaptığ değerlendirme ve tespitleri dikkate alarak Türkiye'nin, uluslararası alanda ekonomik ve mali itibarını korumak için İran ile arasındaki ekonomik ilişkilerinin düzeyini, bu konuda yayınlanan uluslararası düzenlemelere göre gözden geçirmesi ve ayarlamasının bölgesel ekonomik hedefleri açısından faydalı olacağı görülmektedir.

Buna göre, FATF'ın Türkiye hakkında hazırladığı ve yukarıda bahsi geçen son dönemdeki yayınları, Türkiye'nin karaparanın aklanması ve terörizmin finansmanının önlenmesi politikalarında stratejik eksiklikleri olduğunu ve bu konuda uluslararası alanda itibar sorunu yaşadığını göstermektedir. Aynı zamanda uluslararası sermaye akımları ve doğrudan yabancı sermaye yatırımları açısından ülkenin uluslararası alanda sahip olduğu itibar önem arz etmekte olup, Türkiye bu açıdan ülke riski ile de zaman zaman karşılaşmaktadır. Uluslararası derecelendirme kuruluşları ve bazı bağımsız denetim firmaları ülkelerin derecelendirme notlarının değerlendirilmesinde mali faktörler yanında, FATF açıklamalarını da dikkate almaktadır.

Türkiye'nin FATF'a 1991 yılından beri üyeliği göz önüne alınıp, bu tarihten günümüze kadar geçen süre zarfında yeterli uyumu sağlayamamış olması hem FATF'ın hem de Türkiye'nin uluslararası itibarını zedelemekte ve sorgulatmaktadır. Ayrıca, G20 üyesi olduğu halde Türkiye AML/CFT politikalarında çoğu az gelişmiş ve gelişmekte olan ülke ile aynı kategoride yer almaktadır. Dolayısıyla Türkiye, AML/CFT politikalarında küresel finans 
piyasalarına uyumu sağlayacak yönde hareket etmeli ve üyesi olduğu uluslararası kuruluşun amaçlarıyla çelişmeyecek uyumlu faaliyetlerde bulunmalıdır.

\section{SONUÇ}

Karaparanın aklanması ve terörizmin finansmanına ilişkin girişimler gerek ülke gerekse finansal sistem için bir takım riskler yaratmaktadır. Finansal kuruluşun faaliyetlerinin durdurulmasına dahi neden olabilecek riskleri içeren söz konusu girişimlere karşı yeterli tedbirlerin alınmaması yahut finansal kuruluşun bu türden faaliyetlerle ilişkilendirilmesi gerek finansal sektörün gerekse ülkenin uluslararası itibarına önemli ölçüde zarar vermektedir.

Karaparanın aklanması ve terörizmin finansmanının önlenmesi ile ilgili mücadelenin ülke sınırlarını aşıp uluslararası boyuta dönüşmesi, bu alanda uluslararası etkinliği olan kuruluşların teşkil edilmesine ihtiyaç doğurmuştur. Bu amaçla, OECD nezdinde 1989 yılında kurulan FATF adlı kuruluş kurulduğu tarihten bu yana etkinliği ve işlevselliği artan uluslararası bir örgüt yapısına erişmiştir.

FATF'ın ülkeler hakkında yaptığı incelemeler ve gözlemleri neticesinde hazırladığı rapor ve dökümanlar, gerek ülkeler arasındaki ilişkiler gerekse herhangi bir ülke ile ekonomik ilişkiye girmek isteyen uluslararası yatırım ve finans çevreleri tarafından önemle dikkate alınan bir niteliğe ulaşmıştır. Bu çerçevede yakın dönemde söz konusu kuruluşun Türkiye hakkında hazırladığı raporlar ve yayınladığı dökümanlar incelendiğinde, Türkiye'nin bu alanda uluslararası itibar sorunu yaşadığı görülmektedir. Ekim/2012 döneminde terörizmin finansmanı konusunda FATF'ın talep ettiği düzenlemeleri yapmaması nedeniyle Türkiye'nin, en riskli ülkelerin yer aldığı kara liste adlı listeye aktarılması ve FATF üyeliğinden çıkarılması söz konusu olmuş, bu durum hem ülkenin hem de finansal sektörün uluslararası itibarına zarar vermiştir. Ancak, Türkiye'nin 15 Şubat 2013 tarihinde yukarıda bahsedilen eksiklikleri gidermek amacıyla yaptığı yasal düzenlemeler memnuniyetle karşılanmış ve üyeliğinin askıya alınmasından vazgeçilmiştir.

Türkiye, Şubat/2014 döneminde terörizmin finansmanının önlenmesi ile ilgili mevcut risklerini azaltıcı uygulamaya dönük yaptığı düzenlemelerle, Haziran/2014 döneminde FATF'ın yüksek riskli ve işbirliği yapmayan ülkeler kategorisinde daha 1lımlı bir kategori olan FATF ile işbirliği yapan izleme listesine listesine aktarılarak önemli bir fırsat yakalamıştır. Ancak, Türkiye bu listeye aktarılırken de yine Irak, Suriye, Uganda vb. çoğu az gelişmiş ve gelişmekte olan sorunlu ülkelerle aynı kategoride yer almıştır. Çalışmamızın sonucunda, 1991 yılından beri FATF üyesi olduğu halde Türkiye'nin, incelemesini ve analizini yaptığımız 2010 yılından günümüze kadarki dönemde, çoğu az gelişmiş ve gelişmekte olan ülke ile aynı kategoride yer aldığı ortaya çıkmaktadır. Üyesi olduğu FATF'ın amaçlarına uyum sağlamayan Türkiye'nin, bu kuruluş tarafından riskli ya da izleme listelerinde bulunan bir ülke görünümü sergilemesi hem Türkiye'nin hem de FATF'ın uluslararası itibarını sorgulatmakta ve zedelemektedir. Bu amaçla, Türkiye'nin, FATF raporlarında yer alan eksiklikleri dikkate alarak ivedi olarak uluslararası uyumu sağlayacak 
düzenlemeleri yapması ve üyesi olduğu uluslararası kuruluşun amaçlarıyla çelişmeyecek uyumlu faaliyetlerde bulunması hem FATF hem de Türkiye'nin yararına olacaktır.

FATF'ın ülkeler hakkında yaptığı tespitler uluslararası yatırım ve finans çevrelerince önemle üzerinde durulan bir değerde olduğundan bu alandaki uyum yetersizliği, Türkiye'nin gelecekte gelişmiş ülkelerden gelişmekte olan ülkelere yönelik azalma ihtimali söz konusu olan uluslararası sermaye akımları ve doğrudan yabancı sermaye yatırımlarından yeterli seviyede faydalanamamasına neden olabilecektir. Ayrıca, Türkiye'nin bölgesinde orta vadede finans merkezi olma gibi bir hedefinin bulunduğu dikkate alındığında, böylesi bir hedefe ulaşması için uluslararası düzenlemelere ciddi ve gerçek anlamda uyum sağlaması gereği ortaya çıkmaktadır. Bu nedenlerle Türkiye'nin, FATF rapor ve yayınlarında yer alan eksiklik ve yetersizlikleri dikkate alarak ivedi şekilde uluslararası uyumu sağlayacak etkin ve fiilen uygulanacak düzenlemeler yapmasının yararına olacağı görülmektedir. Aksi takdirde Türkiye ekonomisi ve özünde finans sektörünün gelecekte önemli risklerle karşılaşması olasıdır. FATF üyesi olan Türkiye, üyesi olduğu bu kuruluş tarafından belirlenen riskli ve izleme gerektiren ülke listelerinden bir an önce çıkmalıdır.

\section{KAYNAKLAR}

Alp, İnönü Akgün (2005), "Bankalarda Karapara Aklama Risk Yönetimi”, Active, OcakŞubat, Sayı:40, İstanbul, s.77-79

Bartlett, Brent L. (2002), "The Negative Effect of Money Laundering on Economic Development", The Asian Development Bank, Regional Technical Assistance Project No:5967 Countering Money Laundering in The Asian and Pacific Region, May, s.15

Beekarry, Navin (2011), "The International Anti-Money Laundering and Combating The Financing of Terrorism Regulatory Strategy: A Critical Analysis of Compliance Determinants in International Law", Northwestern Journal of International Law\&Business, s. 138-139

Çakır, Alparslan (2006), "Bankacılıkta Operasyonel Risklerin Etkin Yönetiminde Risk Bazlı Müşterini Tanı İlkelerinin Önemi”, Bankacılar Dergisi, Sayı:56, TBB, İstanbul, s.42, 46

Çakır, Alparslan (2010), "Suç Gelirlerinin Aklanması ve Terörizmin Finansmanının Engellenmesi: Banka Riskleri ve Uyum Programının Oluşturulması”, Bankacılar Dergisi, Sayı:74, Eylül, TBB, İstanbul, s. 69-70,72

Daloğlu, Tülin (2014), “Turkey's Financial Practices Under Review”, 13 January, (http://www.al-monitor.com/pulse/originals/2014/01/turkey-money-laundering-graylist.html\#, 10.03.2014)

Doğan, Ayşe (2013), "Banka İşlemleri Yoluyla Karapara Aklama ile Uluslararası Mücadele”, Akademik Perspektif, 20 Haziran, (http://akademikperspektif.com/2013/06/20/bankaislemleri-yoluyla-karapara-aklama-ile-uluslararasi-mucadele, 11.11.2013)

FATF (2007), “Third Mutual Evaluation Report, Anti-Money Laundering and Combating The Financing of Terrorism- Turkey”, 23 February, Paris 
FATF (2009), "FATF Statement Concerning Iran, Uzbekistan, Turkmenistan, Pakistan and Sao Tome and Principe", 26 February, Paris, (http://www.fatf-gafi.org, 14.02.2014)

FATF (2010a), "FATF Public Statement - High Risk and Non-Cooperative Jurisdictions”, 18 February, Paris, (http://www.fatf-gafi.org, 10.02.2014)

FATF (2010b), "FATF Public Statement - High Risk and Non-Cooperative Jurisdictions”, 25 June, Paris, (http://www.fatf-gafi.org, 11.02.2014)

FATF (2010c), "FATF Public Statement - High Risk and Non-Cooperative JurisdictionsImproving Global AML/CFT Compliance: On-Going Process ", Paris, http://www.fatf-gafi.org, 18 February, Erişim Tarihi: 08.02.2014

FATF (2011a), "FATF Public Statement - High Risk and Non-Cooperative Jurisdictions", 25 February, Paris, (http://www.fatf-gafi.org, 16.02.2014)

FATF (2011b), "FATF Public Statement - High Risk and Non-Cooperative Jurisdictions”, 24 june, (http://www.fatf-gafi.org, 16.02.2014)

FATF (2011c), "FATF Public Statement - High Risk and Non-Cooperative JurisdictionsImproving Global AML/CFT Compliance: On-Going Process ”, 25 February, Paris, (http://www.fatf-gafi.org, 06.02.2014)

FATF (2012a), "FATF Public Statement - High Risk and Non-Cooperative Jurisdictions”, 16 February, Paris, (http://www.fatf-gafi.org, 17.02.2014)

FATF (2012b), "FATF Public Statement - High Risk and Non-Cooperative Jurisdictions”, 22 June, Rome, (http://www.fatf-gafi.org, 17.02.2014)

FATF (2012c), "FATF Public Statement - High Risk and Non-Cooperative JurisdictionsImproving Global AML/CFT Compliance: On-Going Process ", 16 February, Paris, (http://www.fatf-gafi.org, 20.02.2014)

FATF (2012d), "FATF Public Statement - High Risk and Non-Cooperative Jurisdictions", 19 October, Paris, (http://www.fatf-gafi.org, 21.02.2014)

FATF (2013a), "About the FATF, Members and Observers", (http://www.fatf-gafi.org, 03.11.2013)

FATF (2013b), "FATF Public Statement - High Risk and Non-Cooperative Jurisdictions", 22 February, Paris, (http://www.fatf-gafi.org, 20.02.2014)

FATF (2013c), "FATF Public Statement - High Risk and Non-Cooperative Jurisdictions", 21 June, Oslo-Norway, (http://www.fatf-gafi.org, 20.02.2014)

FATF (2013d), "FATF Public Statement - High Risk and Non-Cooperative JurisdictionsImproving Global AML/CFT Compliance: On-Going Process", 22 February, Paris, (http://www.fatf-gafi.org, 21.02.2014)

FATF (2013e), "Statement on Turkey", Outcomes of the FATF Plenary Meeting-Paris, 20-22 February 2013, (http://www.fatf-gafi.org, 27.02.2014)

FATF (2013f), "FATF Public Statement - High Risk and Non-Cooperative Jurisdictions", 18 October, Paris, (http://www.fatf-gafi.org, 22.02.2014) 
FATF (2014a), "High Risk and Non-Cooperative Jurisdictions", (http://www.fatfgafi.org/topics/high-riskandnon-cooperativejurisdictions/, 01.02.2014)

FATF (2014b), "FATF Public Statement - High Risk and Non-Cooperative Jurisdictions", 14 February, Paris, (http://www.fatf-gafi.org, 28.02.2014)

FATF (2014c), "FATF Public Statement - High Risk and Non-Cooperative Jurisdictions", 27 June, Paris, (http://www.fatf-gafi.org, 02.07.2014)

FATF (2014d), "FATF Public Statement - High Risk and Non-Cooperative JurisdictionsImproving Global AML/CFT Compliance: On-Going Process ", 27 June, Paris, (http://www.fatf-gafi.org, 02.07.2014)

FATF WATCH (2013), “A Proliferation of Lists”,31 May, (http://fatfwatch.com/ 17.02.2014)

Fundanga, Caleb M. (2003). “ The Role of The Banking Sector in Combating Money Laundering", Speech at Seminar Organized by C and N Centre for Advanced International Studies, Lusaka, 23 January, Zambia

IFAC (International Federation of Accounts) (2004), “Anti-Money Laundering” March, 2nd Edition, USA, ISBN 1-931949-29-8, s.12-13

Keatinge, Tom (2014), “Turkey's Dirty Money: Why Ankara is Still on FATF's Gray List”, 25 February, (http://www.foreignaffairs.com/articles/140970/tom-keatinge/turkeysdirty-money, 01.03.2014)

Kutubi, Shawgat S. (2011), "Combating Money Laundering by The Financial Institutions: An Analysis of Challenges and Efforts in Bangladesh", World Journal of Social Sciences, Vol:1, No:2, May, s.37

MASAK (2014), "Ulusal Mücadele (TF)", (http://www.masak.gov.tr/tr/content/ulusalmucadele-tf/73, 04.03.2014)

Sinkaya, Bayram ve Ali Kemal Yıldırım (2010), “İran Yaptırımlarının Mali Boyutları”, Ortadoğu Analiz, Cilt:2, Sayı:13, Ocak, Ankara, s.41

UNODC (United Nations Office on Drugs and Crime) (2005), "Model Legislation on Money Laundering and Financing of Terrorism", 1 December, Vienna, Austria, (http://www.unodc.org, 21.09.2013)

Ürem, Hakan (2010), "Suç Geliri Aklama Yöntemi: Hawala Sistemi”, 23 Şubat, (http://riskbasedaml.blogspot.com.tr/2010/02/suc-geliri-aklama-yontemi-hawala.html, 07.01.2014)

Üstün, Oktay (2005), "Mali Eylem Görev Gücü’nün (FATF) Dokuz Özel Tavsiyesi”, Bankacılar Dergisi, Say1:52, İstanbul, s.10, 27

Yahşi, Fahrettin (1998), "Karaparanın Aklanmasının Önlenmesine İlişkin Yasal Düzenlemeler Çerçevesinde Bankaların Yükümlülükleri”, Active, Haziran-Temmuz, İstanbul

Yetim, Sedat (2000), “Kara paranın Aklanması, Boyutları ve Mafyokrasi”, Nesil Matbaacılık, Mayıs, İstanbul, ISBN: 975-96531-1-7, s.324 